\title{
A Survey of Arsenic Level in Tube-Wells in Bam Province (Burkina Faso)
}

\author{
Touridomon Issa Somé1, Abdoul Karim Sakira1, Alidou Kaboré1, Aissata Traoré2 \\ ${ }^{1}$ Laboratory of Toxicology, Environment and Health, Doctorate School of Health, University of Ouagadougou, \\ Ouaga, Burkina Faso \\ ${ }^{2}$ Plan Burkina, Ouagadougou, Burkina Faso \\ Email: tsome@ulb.ac.be, tsome@univ-ouaga.bf, asakira@ulb.ac.be
}

Received 2 September 2014; revised 26 September 2014; accepted 21 October 2014

Copyright (C) 2014 by authors and Scientific Research Publishing Inc.

This work is licensed under the Creative Commons Attribution International License (CC BY).

http://creativecommons.org/licenses/by/4.0/

(c) (i) Open Access

\section{Abstract}

Groundwater is a main source of water supply for populations in Burkina Faso where there is a serious problem for drinking water access. However, water quality has not been always followed regularly. Recent studies showed that more than $50 \%$ of drillings in Yatenga province (north of Burkina Faso) have an arsenic concentration above the recommended WHO requirement. Preliminaries studies conducted in Bam (Center North of Burkina Faso) showed high arsenic level in certain localities. This work presents for the first time data on a large scale evaluation that had been performed in all the localities of Bam province in other to have a better assessment of contamination scale. A total of 707 drilling water samples have been selected randomly in 9 communes and analysed for the arsenic level using atomic absorption spectrometry with hydride generation. The results showed that $11 \%$ of drillings have an arsenic concentration above the recommended WHO requirements with Rouko commune having the highest rate of high arsenic level (22\%).

\section{Keywords}

Arsenic, Groundwater, Contamination, Bam Province

\section{Introduction}

Surface water and shallow dug wells are widely used as sources of drinking water. But due to microorganism's contamination, groundwater is the preferred alternative [1] [2]. Consequently, borehole-drilling programs have been undertaken by various agencies including non-governmental organizations (NGOs) and state agencies in recent decades. Most villages have now boreholes (tube-wells) with hand pumps in majority. In the northern part of the country, the problem of water contamination by arsenic has been recently pointed out [3]. There are nu- 
merous toxic symptoms attributed to chronic arsenic exposure [4]-[6] such as specific dermatological effects [6]. A comprehensive review of arsenic toxicology has been published by Hughes et al. [7].

Arsenic contamination originates mainly from natural sources and mining activities tend to widespread it [8]. In Burkina Faso, studies have shown that the northern part of the country presents a geological profile of $\mathrm{Au}$ mineralisation zones in Birimian (lower proterozoic) volcano-sedimentary rocks along with arsenopyrite from which the contamination seems to originate [9]. We have recently introduced a study on the arsenic exposure in Yatenga province in North of Burkina Faso [3] due to tube-wells contamination by arsenic. Toxicological effects we noticed, such as gastrointestinal problems and skin diseases, in local population were in agreement with literature data on arsenic heath problem [2].

Bam province is located in south of Yatenga province and presents the same geological characteristics as in the northern part. Preliminary analyses of water quality have shown the presence of arsenic in tube-wells. This large scale study was undertaken in order to have an overview of the water quality in the province in terms of arsenic contamination.

\section{Methodology}

\subsection{Sampling}

The study was conducted in the province of Bam located in the central northern part of Burkina Faso. The province of Bam has 9 administrative communes (Bourzanga, Guibaré, Kongoussi, Nasséré, Rollo, Rouko, Sabcé, Tikaré and Zimtenga). It has an area of $4084 \mathrm{~km}^{2}$ and includes 241 villages with a population of about 300,000. It is a gold mining area. All functional drillings in the communes of Guibaré and Sabcé (200) were subjected to a systematic sampling because previous analyses have shown high arsenic concentration. The choice of drillings to be sampled in other communes was done considering a stratified random sampling method taking into account the nature of the ground (risk area or undefined risk area). Two levels of stratification were retained. The first level consisted of drillings in the risky area based on previous finding and the second level represented all drillings in other parts of the province.

\subsection{Water Collection}

All the samples were taken in $33 \mathrm{~mL}$ polyethylene bottles previously treated with nitric acid $(10 \% \mathrm{v} / \mathrm{v})$ and rinsed with Milli-Q water. Water was pumped from wells for 10 to 15 min before sample collection, in order to flush out all retained water in the pipes. For the conservation, each sample was acidified with $6.6 \mathrm{~mL}$ hydrochloric acid (37\%).

\subsection{Sample Treatment and Analysis}

The samples from Sabcé and Guibaré were analysed for arsenic but also for temperature, conductivity, pH, and turbidity. The samples from the other communes were only analysed for their arsenic content.

\subsubsection{Determination of the $\mathrm{pH}$}

It was measured at sampling using a portable $\mathrm{pH}$-meter (Hanna Instruments). The precision of the determination was \pm 0.02 unit of $\mathrm{pH}$.

\subsubsection{Determination of the Temperature and Conductivity}

Conductivity is dependent on the ion concentrations, the nature of the ions, the temperature of the solution, the viscosity of the solution. The measurement of conductivity was realized on site using a multiparameter portable conductimeter (Hanna Instruments). The results were expressed in $\mu$ siemens per centimeter $(\mu \mathrm{S} / \mathrm{cm})$.

\subsubsection{Determination of Turbidity}

Turbidity was measured on the site using an optical turbidimeter and expressed in Nephelometric Turbidity Unit (NTU). The normal values should be less than 5.0 NTU.

\subsubsection{Determination of Total Arsenic by Atomic Absorption Spectrometry (AAS)}

All the samples were digested with a mixture of hydrogen chloride and nitric acid (3:1) in a microwave digester 
(MARS XPRESS CEM, UK). Arsenic content in water was then determined by atomic absorption spectrophotometry using a hydride generation method (Varian AAS 240 FS USA). Milli-Q water acidified with hydrogen chloride was used as control. A commercial standard solution of arsenic was used for linearity (As III 1000 ppm Atomic Spectroscopy Standard Solution Fluka, Switzerland). The method used for the determination of total arsenic was based on the direct measurement of the specific absorbance generated by the thermal decomposition hydride arsenic. The reduction of arsenic (V) to arsenic (III) was done with potassium iodide (KI) and acid ascorbic solution and the generation of arsenic hydride (III), $\mathrm{AsH}_{3}$ was done by reaction with sodium tetra hydroborate in hydrochloric acid medium.

\section{Results and Discussions}

\subsection{Analytical Method}

The selected analytical parameters are presented in Table 1. The determination of the concentration of each element was realised from the calibration curve using the specific absorbance of arsenic. The results are expressed in microgram per liter $(\mu \mathrm{g} / \mathrm{L})$ or $\mathrm{ppb}$.

\section{2. pH, Turbidity and Bacteria Contamination}

The results of the field measurement of $\mathrm{pH}$, turbidity and bacteria contamination in up to 200 drillings in Guibaré and Sabcé are presented in Table 2.

The control of the water $\mathrm{pH}$ is useful for the estimation of corrosion risk and scaling. In general, the corrosion of a metal becomes important at $\mathrm{pH}$ values lower than approximately 6.5 and incrustation of matters and scaling are especially important a $\mathrm{pH}$ values above 8.5 . Thus the acceptable $\mathrm{pH}$ scale in drilling water is between 6.5 and 8.5. The water turbidity is due to the presence of the finely divided suspended matter (clay, silt, organic matters...). Turbidity does not represent a direct health risk but a high value can contribute to the decrease of the disinfection effectiveness and generate microbiological risks. The percentage of abnormal turbidity (8.0\%) can

\begin{tabular}{|c|c|}
\hline \multicolumn{2}{|c|}{ Spectrophotometer parameters (Varian AAS 240 FS, USA) } \\
\hline Wavelength & 193.7 \\
\hline Exit slit & $0.7 \mathrm{~nm}$ \\
\hline Ultra-lamp intensity & $10 \mathrm{~mA}$ \\
\hline Signal measurement mode & pic high \\
\hline Linearity & $2.5-15.0 \mathrm{ppb}\left(\mathrm{r}^{2}=0.99\right)$ \\
\hline Precision $(\mathrm{n}=3)$ & $5.6 \%$ \\
\hline LOQ & $2.5 \mathrm{ppb}$ \\
\hline LOD & $0.5 \mathrm{ppb}$ \\
\hline $\mathrm{NaBH}_{4}$ concentration & $0.6 \%(\mathrm{~m} / \mathrm{v})$ stabilised with $\mathrm{NaOH}(0.5 \%)$ \\
\hline $\mathrm{NaBH}_{4}$ flow rate & $4-6 \mathrm{~mL} / \mathrm{min}$ \\
\hline $\mathrm{HCl}$ concentration & $5 \mathrm{M}$ \\
\hline $\mathrm{HCl}$ flow rate & $9-11 \mathrm{~mL} / \mathrm{min}$ \\
\hline Argon flow rate & $40-60 \mathrm{~mL} / \mathrm{min}$ \\
\hline
\end{tabular}

Table 2. Results of water pH, turbidity and bacteria concentration in 200 drillings in Guibaré and Sabcé.

\begin{tabular}{ccccc}
\hline & Sample size & \% of water out of $\mathrm{pH}$ scale & $\begin{array}{c}\text { \% of water out of turbidity } \\
\text { scale }\end{array}$ & $\begin{array}{c}\text { \% of bacteria contaminated } \\
\text { waters }\end{array}$ \\
\hline Guibaré & 111 & $4.5 \%$ & $7.2 \%$ & $10.8 \%$ \\
Sabcé & 89 & $5.6 \%$ & $8.9 \%$ & $5.6 \%$ \\
Guibaré and Sabcé & 200 & $5.0 \%$ & $8.0 \%$ & $8.5 \%$ \\
\hline
\end{tabular}


be related to the bacteriological contamination (8.5\%). The presence of organic particles contributes to the turbidity and may favour bacteria growth. Underground waters are normally protected from any risk of pollution and do not contain coliform bacteria.

\subsection{Arsenic Concentration}

The arsenic concentration was measured in 707 drillings all over the province of Bam. The data on Table 3 show the presence of arsenic at different concentrations in drinking water from the drillings.

The proportion of drillings with high arsenic concentration compared to the WHO [10] standard value varied from 7.4\% in Zimtenga till 22.6\% in Rouko. Only the commune of Bourzanga in the all province had wells in compliance with acceptable arsenic concentrations. We found in previous study [3] that up to 50\% of water from drillings in Yatenga province (next to Bam) was also contaminated. Population are exposed to arsenic contamination through the consumption of this underground water in some extent. The situation is similar to West Bengal in India where more than $50 \%$ of groundwater from drilling had an arsenic concentration higher than the WHO standard of $10 \mathrm{ppb}$ and $25 \%$ had arsenic concentration above $50 \mathrm{ppb}$ [11]. Water from tubular wells can also be contaminated in the same area [11]. Cutaneous lesions were observed in all arsenic contaminations areas even if the arsenic concentration respects WHO requirements [3] [11]. Like in the province of Yatenga, the water contamination seemed to be of natural original since no human activity was found [12]. The presence of arsenic in water was therefore attributed to the volcano-birrimian nature of the soil in this area. This soil contains high arsenic level reflecting the oxidation/weathering of arsenopyrite [3]. Communes of Rouko and Sabcé have the highest frequency of contaminated drills (above $100 \mathrm{ppb}$ ). Indeed, most of the drills with arsenic concentration above $100 \mathrm{ppb}$ were located in these two communes. The village of Bissa in the commune of Sabcé was the first village where the population displayed cutaneous signs prompting the search of the causes that led to the discovery of arsenic contamination. This village must dawned special attention, because more than $50 \%$ of the population had cutaneous signs due to the unique drill in the village which was tested for $380 \mathrm{ppb}$ and $430 \mathrm{ppb}$ of arsenic during two control campaigns.

\section{Conclusion}

High arsenic concentration in groundwater in the province of BAM in the northern part of Burkina Faso was reported in this large scale study. The results showed that $11.3 \%$ of water from the drillings had arsenic concentration above the recommended WHO requirement. The arsenic contamination level in some localities in this study prompted local authorities to close water accessibility which generated a dramatic situation. This study

Table 3. Results of arsenic concentration measurements of drillings in Bam province.

\begin{tabular}{|c|c|c|c|c|c|c|c|c|c|}
\hline \multirow{2}{*}{ Commune } & \multirow{2}{*}{ Sample size } & \multirow{2}{*}{$\begin{array}{c}\text { Minimum } \\
(\mu \mathrm{g} / \mathrm{L})\end{array}$} & \multirow{2}{*}{$\begin{array}{c}\text { Maximum } \\
(\mu \mathrm{g} / \mathrm{L})\end{array}$} & \multirow{2}{*}{$\begin{array}{c}\% \text { of } \\
\text { contamination } \\
\text { above } 10 \mu \mathrm{g} / \mathrm{L}\end{array}$} & \multicolumn{5}{|c|}{ Arsenic concentration $(\mu \mathrm{g} / \mathrm{L})$} \\
\hline & & & & & $<0.5$ & $0.5-10$ & $10-50$ & $50-100$ & $\geq 100$ \\
\hline Guibaré & 111 & $<0.5^{*}$ & 34.3 & $10.8 \%$ & 52 & 47 & 12 & 00 & 00 \\
\hline Sabcé & 89 & $<0.5$ & 631 & $16.8 \%$ & 32 & 42 & 9 & 01 & 05 \\
\hline Kongoussi & 151 & $<0.5$ & 368 & $11.2 \%$ & 80 & 54 & 13 & 02 & 02 \\
\hline Bourzanga & 77 & $<0.5$ & 0.64 & $0.0 \%$ & 76 & 01 & 00 & 00 & 00 \\
\hline Nasséré & 38 & $<0.5$ & 24.2 & $10.5 \%$ & 24 & 10 & 04 & 00 & 00 \\
\hline Rollo & 45 & $<0.5$ & 48.5 & $8.3 \%$ & 35 & 06 & 04 & 00 & 00 \\
\hline Rouko & 53 & $<0.5$ & 228 & $22.6 \%$ & 20 & 21 & 07 & 01 & 04 \\
\hline Tikaré & 76 & $<0.5$ & 25.7 & $14.4 \%$ & 35 & 30 & 11 & 00 & 00 \\
\hline Zimtenga & 67 & $<0.5$ & 46.7 & $7.4 \%$ & 32 & 30 & 05 & 00 & 00 \\
\hline Bam Province & 707 & $<0.5$ & 631 & $11.3 \%$ & 386 & 241 & 65 & 04 & 11 \\
\hline
\end{tabular}

*Not detectable (instrument detection limit: $0.5 \mu \mathrm{g} / \mathrm{L}$ ); WHO standard is $10 \mu \mathrm{g} / \mathrm{L}$ (10 ppb). 
showed for the first time that populations of the Bam province in Burkina Faso are highly exposed to arsenic contamination through groundwater and actions must be taken to alleviate the consequences. These results combined with our previous findings make the arsenic contamination of water an incoming serious health problem in the northern part of the country.

\section{Acknowledgements}

The authors want to thank Plan Burkina for financing the study.

\section{References}

[1] Schmoll, O., Howard, G., Chilton, J. and Chorus, I. (2006) Protecting Groundwater for Health: Managing the Quality of Drinking-Water Sources. World Health Organization, IWA Publishing, London.

[2] Smith, H.S., Lingas, E.O. and Rahman, M.M. (2000) Bulletin of the World Health Organization, 78, 1093-1103.

[3] Somé, I.T., Sakira, A.K., Ouédraogo, M., Ouédraogo, T.Z., Guissou, I.P., Sondo, B. and Traoré, A. (2012) Arsenic Levels in Tube-Wells Water, Food, Residents' Urine and the Prevalence of Skin Lesions in Yatenga Province, Burkina Faso. Interdisciplinary Toxicology, 5, 101-104. http://dx.doi.org/10.2478/v10102-012-0007-4

[4] WBWSP (World Bank Water and Sanitation Program) (2005) Towards a More Effective Operational Response to Arsenic Contamination of Groundwater in South and East Asian Countries. WBWSP, Washington DC.

[5] Singh, A.P., Goel, R.K. and Kaur, T. (2011) Mechanisms Pertaining to Arsenic Toxicity. Toxicology International, 18, 87-93. http://dx.doi.org/10.4103/0971-6580.84258

[6] Guha Mazumder, D.N. (2003) Chronic Arsenic Toxicity: Clinical Features, Epidemiology, and Treatment: Experience in West Bengal. Journal of Environmental Science and Health, Part A: Toxic/Hazardous Substances and Environmental Engineering, 38, 141-163. http://dx.doi.org/10.1081/ESE-120016886

[7] Hughes, M.F., Beck, B.D., Yu, C., Lewis, A. and Thomas, D.J. (2011) Arsenic Exposure and Toxicology: A Historical Perspective. Toxicological Sciences, 123, 305-332. http://dx.doi.org/10.1093/toxsci/kfr184

[8] Smedley, P.L. and Kinniburgh, D.G. (2002) A Review of the Source, Behaviour and Distribution of Arsenic in Natural Waters. Applied Geochemistry, 17, 517-568. http://dx.doi.org/10.1016/S0883-2927(02)00018-5

[9] Smedley, P.L., Knudsen, J. and Maiga, D. (2007) Arsenic in Groundwater from Mineralised Proterozoic Basement Rocks of Burkina Faso. Applied Geochemistry, 22, 1074-1092. http://dx.doi.org/10.1016/j.apgeochem.2007.01.001

[10] WHO (2004) Guidelines for Drinking-Water Quality. World Health Organization, Geneva.

[11] Rahman, M.M., Sad Ahamed, K.S.M., Chowdhury, K.U., et al. (2005) Arsenic Contamination of Ground Water and Its Health Impact on Residents in a Village of in West Bengal, India. Bulletin of World Health Organization, 83, 49-57.

[12] Ahsan, H., Chen, Y., Parvez, F., et al. (2006) Arsenic Exposure from Drinking Water and Risk of Premalignant Skin Lesions in Bangladesh: Baseline Results from the Health Effects of Arsenic Longitudinal Study. American Journal of Epidemiology, 163, 1138-1148. http://dx.doi.org/10.1093/aje/kwj154 
Scientific Research Publishing (SCIRP) is one of the largest Open Access journal publishers. It is currently publishing more than 200 open access, online, peer-reviewed journals covering a wide range of academic disciplines. SCIRP serves the worldwide academic communities and contributes to the progress and application of science with its publication.

Other selected journals from SCIRP are listed as below. Submit your manuscript to us via either submit@scirp.org or Online Submission Portal.
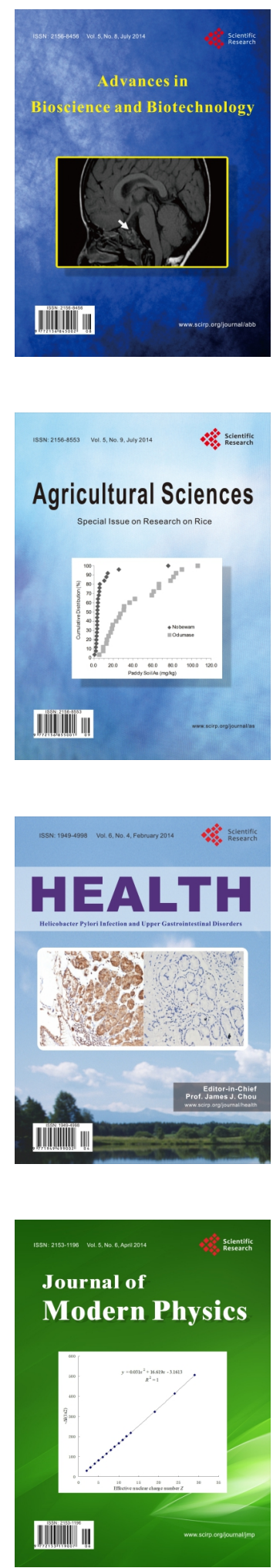
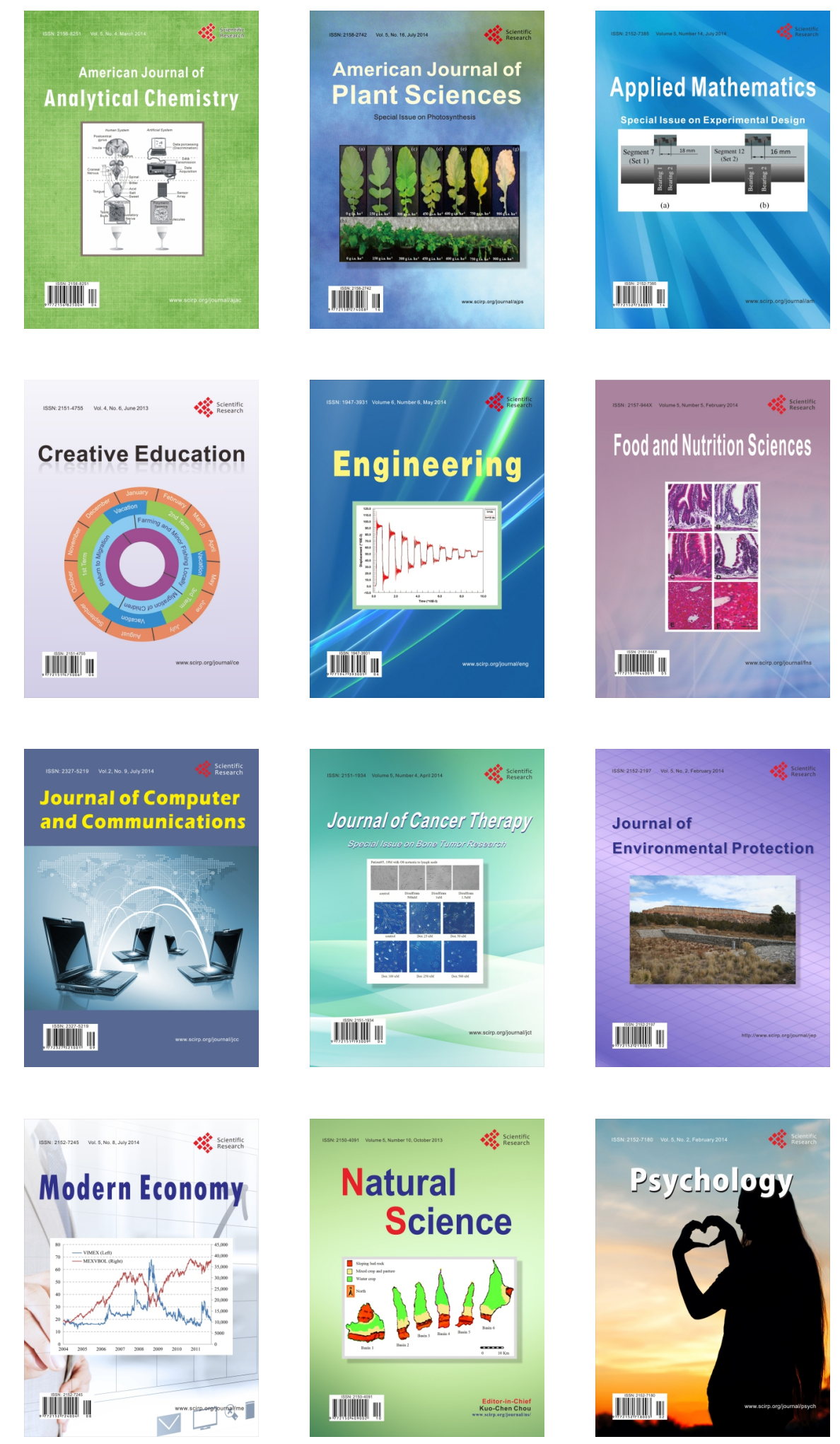